\title{
An Investigation Into Alternative Television Viewership Habits Of College Students
}

Katie J. Damratoski, Southeastern Louisiana University, USA

April R. Field, Southeastern Louisiana University, USA

Katie N. Mizell, Southeastern Louisiana University, USA

Michael C. Budden, Southeastern Louisiana University, USA

\begin{abstract}
Television viewership through the use of digital video recorders (DVRs) and the Internet are affecting viewership statistics. The utilization of the Internet by students to view television programs mandates that future marketing efforts be directed more toward the Internet instead of traditional television advertisements. Research focused on the television viewing habits of college students, current challenges in television advertising and marketing and the increasing use of DVRs and the Internet are investigated.
\end{abstract}

Keywords: Television; Viewership; Ratings; Alternative Media; DVRs

\section{INTRODUCTION}

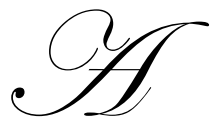

$s$ the number of Generation Y'ers using nontraditional means for watching television increases, the need for further research into the viewership habits of college students is needed. The habits of current college students - a major segment of Generation Y - will be central to the future of many marketing strategies. This generation is accustomed to having everything at their finger tips on their own time and schedule. A recent study stated with the increase in internet usage among college students, marketers have reached an era where traditional means of advertising have shifted to the World Wide Web. "These young adults, accompanied with their better than $\$ 200$ billion spending budget, are "clicking" their way into being one of the hottest target markets in the new millennium. In addition, their influence on family consumer behavior is such that Noble, Haytko and Phillips (2009) proffer Generation Y's total purchasing behavior including their influence on parental purchasing is $\$ 600$ billion.

This segment is comprised of technologically savvy but skeptical consumers, who as noted by Dunne and Lusch, who are a difficult group to reach as they don't use magazines and newspapers for gathering information (2008, p. 77). Since the traditional means of media outreach has taken a heavy hit, marketing firms will need to find creative ways using the Internet to tap into the huge number of internet users (Jones, Budden, Budden \& Foster, 2007)."

College students comprise a powerful market force and it is crucial for marketers to identify the various means in which this evolving group receives information. As one report indicates that 18-24 year-olds are more likely to purchase a product on the spur of the moment (Lamb, Hair and McDaniel, 2006) it is important that marketers reach this group prior to the purchasing encounter. At least one brand expert believes that 21 year olds are in a period of transition and not yet ready to make strong brand attachments (Lamb, Hair and McDaniel 2006, p.81). Thus, the ability to reach and influence this market is paramount if one is to optimize their marketing strategy.

Television has been one of the most popular means for delivering entertainment, advertising and information to the public. The Nielsen Company reported in January of 2009 that the average American spent more than 151 hours per month watching television and seven more watching recorded programs (Jones, 2009). But, traditional television viewing is declining while other technologies that provide access keep growing (Selbert, 2009). 
The survey in 2009 by Nielsen reported that Americans spend 2.8 hours per month watching video online. However, Nielsen found that over 123 million individuals view streaming video on websites: $43 \%$ as many as reported watching standard television (Jones, 2009). With such a rise in online viewing and a proclivity of Generation Y'ers to use technology to seek (and avoid) information sources, it is important to consider how this phenomenon may affect the future of television as an advertising medium. In other words, as seen in Model 1 - consumers can purposely avoid exposure to advertising messages by either avoiding the advertisement physically by leaving the room, changing channels (channel surfing), etc. Or, consumers can use technology to avoid advertisements.

Model 1:

Advertising Exposure Model

Advertising

Exposure

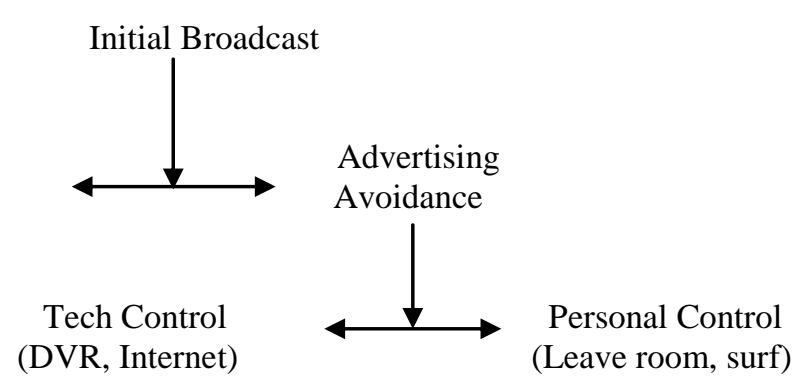

Accordingly, this article will focus on understanding college student television viewing habits. Specifically, a review of secondary research on viewing habits and trends, the impact on advertising and the ability to reach college students, the use of technology by students in viewing "television" shows, and the results of a survey of college students to give particular insight into more recent activities, follows.

\section{COLLEGE STUDENTS AND TELEVISION VIEWING HABITS}

In 2009, the United States economy's scorecard showed that television viewing was at an "all-time high." On average, Americans watched up to five hours of TV every day (Nelson, 2009). Even though 18-24 year olds can be monitored in homes, one Nielsen Media Research initiative in 2004 tracked college students which showed their viewership differed from the general 18-24 year old audience (Fitzgerald, 2007).

For many years, college students who moved away from home were not included in studies, so campus viewing was an unknown. To track this audience, Nielsen instituted a three-year pilot program that networks sponsored. Meters were set up in college television viewing areas such as dorms and sorority houses. The results showed an increase in ratings for many shows (Steel, 2007). One area that showed a difference in college students from their 18-24 year old non-degree seeking friends was that college students watch a plethora of television after 11 p.m. (Fitzgerald, 2007).

Along with television viewing, college students' internet usage is significantly increasing (Odell, Korgen, Schumacher \& Delucchi, 2000). This is important to networks to consider because those patterns can play into affect for viewing television programs after their initial showing. A study completed in 2007 identified that on average, a college students spends almost 10 hours per week on the Internet (Budden, Anthony, Budden \& Jones, 2007). With the ability of consumers to view television on the Internet as well as through digital video recording devices (DVRs), a need for consolidated ratings of these venues outside of cable television existed. Until recently, there was not a way to include audiences who record shows and watch them on playback days after airing. A new measurement system has been introduced by a ratings provider, OzTam, to include homes that use personal video recorders (PVRs). Instead of only receiving feedback from live ratings, networks can now get a more "accurate picture of their audiences" by including the percentage of homes that "time-shift" their TV viewing through digital video recorders. OzTam's figures showed that people are increasing their use of such recording devices to watch television. This information will prove to be vital to some brand campaigns, especially those that are not time sensitive (Johnson, 2010). 
A group has formed with the intention of offering funding for those wanting to create a new measurement for the TV and video industry, called the Coalition for Innovative Media Measurement or CIMM. A challenge is some networks are offering free content on their websites. This potentially creates a questionable situation because it does not take into account the current affiliate fee-based distribution model to show whether viewers of internet programs are only watching their programs on the Internet or if they are an audience that also watches their network programs on television. A "TV Everywhere" model has been established where consumers sign in to prove that they are cable subscribers to help assess those who access their sites. However, this presents a challenge with an evergrowing effortless society. Eventually college students could find an easier outlet for viewing programs, whether legally or not (Atkinson, 2009).

\section{TELEVISION ADVERTISING AND MARKETING}

Digital video recorders and the Internet have changed the way many Americans watch television. These technologies allow viewers to watch television at their own convenience and pace. Along with this shift in television viewing habits is a major obstacle for companies who utilize traditional television advertising. It was stated in a recent study, the fundamental effect of DVR proliferation is due to a shift in control, what was once in the hands of the networks and advertisers is now in the hands of the viewers (Wilbur, 2008). In short, consumers can avoid advertising if they so desire through the use of technology.

Viewer advertisement avoidance has always been a challenge for marketers; viewers have long been flipping channels, diverting attention to companions and leaving the room for as long as television has been in existence, but with the DVR they can avoid the commercials and not have to waste any time doing so. Technology has furthered desire for instant access to all things and television is no exception. TiVo is selling network secondby-second ratings of programs and commercials and plans to add demographic data about the viewers. This information provides a clearer picture of the people who are skipping advertisements (Vranica, 2007).

Television ratings allow marketers to quantify viewers, in turn, allowing them to choose times, days and target markets for their ads. The Nielsen Company has always been the primary source of ratings information for television networks as well as companies seeking to advertise on these networks. The company uses advanced data collection methods and measurements to help businesses turn data into customer intelligence (Nielsen Website). Traditional techniques have been challenged by the networks who understand the urgency to create a model for online viewing that deters the viewers from neglecting the network completely and find a way to present content in branded environments compatible with the networks (Robbins, 2009). Many television networks have recently formed a Coalition for Innovative Media Measurement which could create fresh competition for the Nielsen Company. The effort seeks to measure audiences across television, the Web and even mobile devices. While it does not plan to immediately replace Nielsen, the coalition will explore options to work with competitors of Nielsen, create a new competitor or use Nielsen as a data provider (Schechner \& Vranica, 2009).

Not only have television networks been combating the use of DVRs, but also the use of online entertainment companies such as Hulu and YouTube that show their programs for free. In order to compete, many television networks have begun voluntarily uploading their own content allowing viewers to watch at their convenience. These same networks are noticing the shift in viewing habits and therefore increasing the amount of advertising on their websites. One network in particular, the $\mathrm{CW}$, plans to increase their online advertising to almost equal the amount of advertising seen on their television network (Steinberg, 2010).

\section{DIGITAL VIDEO RECORDERS AND THE INTERNET}

"When the big screen in our living room finally converges into one that can deliver both TV and internet content, the game will certainly change (Selbert, 2009)." As technology improves, it is probable that more American's will be utilizing DVRs and the Internet to watch television on their schedule and without commercial interruptions, especially tech-savy college students. Nielsen reported in 2009 that video streams online rose from more than 95.3 billion in 2008 to more than 104.3 billion between January and October of 2009. Similarly, an April 2009 survey by Pew Research Center's Internet and American Life Project found the use of video-sharing sites nearly doubled from 2006-2009. Hulu, one of the top video sharing sites owned by Walt Disney, News Corp. and 
NBC Universal, reported 583.2 streams per month for September 2009, a 400\% increase in just one year. Hulu has quickly climbed to one of the most visited sites in the U.S. The average online viewer on Hulu watched almost 5.5 hours of video. In April 2009, 75\% of U.S. internet users watched 14.5 billion on-line videos (Grant, Kaminer \& Lee, 2009).

Many U.S. college students are decreasing their use of television broadcasts, instead, piecing together content to fit their own schedules and social life (Barkhuus, 2009). Television is increasingly being watched 'time shifted' through recordable means like TiVo's, DVD recorders and now the Internet (Barkhuus, 2009). Studies have shown, online video watching among young adults is skyrocketing. Nine in ten internet users ages 18-29 say they watch content on video sharing sites, and 36\% report doing so on a typical day. Pew Research Center's Internet and American Life Project found watching online videos outranks many online activities (Madden, 2010).

Recent data released by Interpublic Group's Mediabrands reports that at the end of March 2009, 27\%, or 31 million, U.S. households have DVRs and they expect this to rise to $42 \%$ by 2014 . Along with the use of DVRs in the home, other entertainment devices are able to stream video to the viewer on their own schedule. Devices such as Blue-Ray, Microsoft's Xbox, Roku, and Apple TV are just a few services that stream movies and other web-ready content (Selbert, 2009).

\section{RESEARCH METHODOLOGY}

A convenience sample of college students at a university in the southern U.S. ( $n=228$ ) was used to test several hypotheses related to television viewing. To gather pertinent data, a questionnaire was developed and pretested prior to its final use. Questionnaires were distributed in March 2010 via direct distribution to students in the classes of cooperative professors and through the campus email system.

Three business professors were cooperative in allowing the researchers to enter their classes at the beginning of each session and request that students participate in the study. Students were apprised of the topic of the study, given directions and asked to participate. Participation was voluntary and anonymous. Questionnaires were distributed to all students present. More than $98 \%$ students in the targeted classes participated.

The email request for participation, sent to approximately 200 students included a link to the questionnaire which had been prepared under Google Documents. The e-mail addresses of the sample were obtained through the university student directory in a systematic but non-random manner. Essentially, the names were obtained by selecting students alphabetically by last name.

In the end, 228 usable questionnaires were obtained. As might be expected, the majority of respondents were between 19 and 23 years of age. A large majority of the respondents (84\%) reported they were undergraduate students. GPAs of the students typically were in the2.0 to 3.49 range. Males comprised $45 \%$ of the respondents while females comprised 55\% (university-wide, approximately $65 \%$ of students are female).

Data was entered into an Excel spreadsheet and checked for accuracy. The data was imported into SPSS for analysis. Frequencies, cross-tabs and correlation analyses were conducted to assess the findings.

\section{FINDINGS}

\section{Objective 1}

The first objective was to determine "prime time" television and when college students are actually watching television. When comparing the two it was found the majority of the students consider prime-time to be 7:00pm to $10: 00 \mathrm{pm}$. However, $91.6 \%$ reported watching television from $6: 00 \mathrm{pm}$ to $11: 59 \mathrm{pm}$. In addition to time, when asked what day they most likely watch television $22 \%$ of respondents reported Sunday and $20.6 \%$ reported Monday. 


\section{Objective 2}

The second objective was to determine the most popular genre of television among college students. The findings revealed $26.6 \%$ of students surveyed prefer to watch Situational Comedy / Comedy, followed by Sports/ Reality at approximately $21 \%$ each.

\section{Objective 3}

The third objective was to investigate whether the usage of DVRs and the Internet increases the amount of television watched per day by college students. When asked to exclude the usage of DVRs and the Internet, $54.4 \%$ of the participants responded they watch up to 2 hours/day while $26.8 \%$ watch 4 to 6 hours/day. When asked to include the usage of DVRs and the Internet the percentage of participants who watch up to 2 hours/day decreased and the percentage of those who watch 4 to 6 increased. This indicates the usage of DVRs and the Internet increases the overall amount of time college students watch television in a given day, and Chart 1 indicates such. Interestingly, $16 \%$ report using DVRs and the Internet to avoid commercials and save time.

\section{Chart 1}

\section{Television Viewership: Excluding and Including the Use of DVRs and the Internet}
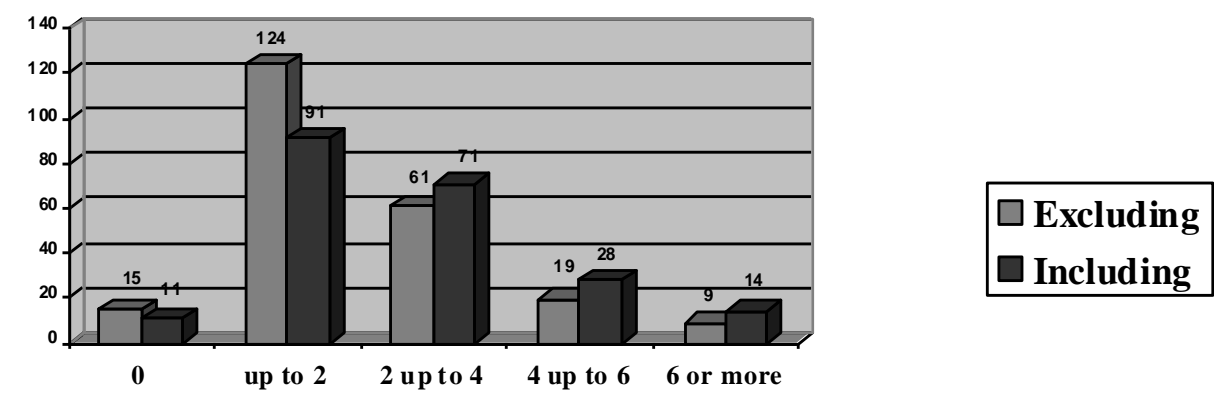

Hours/Day Spent Watching TV

\section{Objective 4}

The fourth objective was to discover the main reason(s) students watch recorded television on a DVR and/or the Internet and which websites were most often utilized. Almost half of the respondents (47.2\%) indicated their main reason for watching recorded television was because they missed the regularly scheduled broadcast. Avoiding commercials and conflicts with other programs were indicated as other reasons the participants utilized recorded television. When using the Internet to view recorded television programs YouTube.com and Network websites experienced equal utilization (26\% each).

\section{Objective 5}

The fifth objective was to determine if student involvement in on-campus activities affects the amount of television watched by the participants as well as the affects of television viewership on Grade Point Average. Of the 112 who were not involved in campus activities, $64 \%$ watch 6 or more hours of television each day (See Table 1). 
Table 1

\begin{tabular}{|l|l|c|c|}
\hline & & \multicolumn{2}{|c|}{ Active Involvement in On-campus Activities } \\
\hline \multirow{3}{*}{$\begin{array}{l}\text { Amount of time spent } \\
\text { watching television per day }\end{array}$} & & Involved & Uninvolved \\
\cline { 2 - 4 } & 0 hrs/day & $5(2.35 \% 0$ & $6(2.82 \%)$ \\
\cline { 2 - 4 } & Up to 2 hrs/day & $44(20.66 \%)$ & $47(22.07 \%)$ \\
\cline { 2 - 4 } & 2 up to 4 hrs/day & $36(16.90 \%)$ & $34(15.96 \%)$ \\
\cline { 2 - 4 }$* n=213$ & 4 up to 6 hrs/day & $11(5.16 \%)$ & $16(7.51 \%)$ \\
\cline { 2 - 4 } & 6 or more hrs/day & $5(2.35 \%)$ & $9(4.23 \%)$ \\
\hline
\end{tabular}

As shown in Table 2 there was not a significant correlation between the amount of television students watched and their G.P.A.

Table 2

\begin{tabular}{|c|c|c|c|c|c|c|}
\hline & & \multicolumn{5}{|c|}{ GPA } \\
\hline \multirow{6}{*}{$\begin{array}{l}\text { Amount of time } \\
\text { spent watching } \\
\text { television per day }\end{array}$} & & Below 1.0 & 1.0-1.99 & 2.0-2.99 & 3.0-3.49 & 3.5-4.0 \\
\hline & 0 hrs/day & $0(0.0 \%)$ & $0(0.0 \%)$ & $7(3.29 \%)$ & $4(1.88 \%)$ & $0(0.0 \%)$ \\
\hline & Up to $2 \mathrm{hrs} /$ day & $0(0.0 \%)$ & $1(0.47 \%)$ & $31(14.55 \%)$ & $30(14.08 \%)$ & $29(13.62 \%)$ \\
\hline & 2 up to $4 \mathrm{hrs} /$ day & $0(0.0 \%)$ & $1(0.47 \%)$ & $27(12.68 \%)$ & $21(9.86 \%)$ & $21(9.86 \%)$ \\
\hline & 4 up to $6 \mathrm{hrs} /$ day & $0(0.0 \%)$ & $0(0.0 \%)$ & $18(8.45 \%)$ & $6(2.82 \%)$ & $3(1.41 \%)$ \\
\hline & 6 or more hrs/day & $1(0.47 \%)$ & $0(0.0 \%)$ & $4(1.88 \%)$ & $7(3.29 \%)$ & $2(0.94 \%)$ \\
\hline
\end{tabular}

$*_{n}=213$

\section{Objective 6}

The sixth objective was to determine if employment impacts student viewership. Of the 161 respondents who are employed only $15.5 \%$ watch television at work and $47.8 \%$ are aware their employer restricts or prohibits watching television while at work.

Table 3

\begin{tabular}{|l|l|c|c|}
\hline & & \multicolumn{2}{|c|}{ Employment } \\
\hline \multirow{4}{*}{$\begin{array}{l}\text { Amount of time spent } \\
\text { watching television per } \\
\text { day }\end{array}$} & & Employed & Unemployed \\
\cline { 2 - 4 } & 0 hrs/day & 7 & $4(1.87 \%)$ \\
\cline { 2 - 4 } & Up to 2 hrs/day & $77(35.98 \%)$ & $14(6.54 \%)$ \\
\cline { 2 - 4 } & 2 up to 4 hrs/day & $53(24.77 \%)$ & $18(8.41 \%)$ \\
\cline { 2 - 4 } & 4 up to 6 hrs/day & $15(7.01 \%)$ & $12(5.61 \%)$ \\
\cline { 2 - 4 } & 6 or more hrs/day & $9(4.21 \%)$ & $5(2.34 \%)$ \\
\hline
\end{tabular}

$* n=214$ (percentages are rounded for each column that should total 100\%)

As shown in Table 3, the majority of employed students watch up to 2 hours of television per day where as the majority of unemployed students watch 2 up to 4 hours per day.

\section{DISCUSSION}

This study supports previous research indicating the viewership of television shows through the use of DVRs and the Internet is increasing, especially among Generation Y college students. Results were consistent with what was expected regarding the amount of television watched in a given day including and excluding DVRs and the Internet. The amount of television viewership by hours per day increased through the use of DVRs and the Internet. Students are watching "television" but are doing so on their time and according to their rules. DVRs, the internet and still developing technologies are allowing college students to view television at times and days that are convenient to the student, and even allows them to decide whether or not to view advertising - a thought that sends shudders down the backs of many marketers. 
To reach students who utilize the Internet to view television programs, future marketing efforts will have to be directed more toward the Internet instead of traditional television advertisements. Research has proven hopeful for advertisers as there are now more ways to gauge ratings of internet video streaming and even more specifically, the viewership of college students. Though the use of DVRs may seem like a threat to most advertisers, it should also be viewed as an opportunity to reach their target market through a variety of advertising channels such as the Internet.

More recently, cell phones are allowing users access to a variety of entertainment options at their fingertips. This merging of technologies offers opportunities for college students to further adapt media offerings to their needs and desires. The increased use of phones as a communication and entertainment medium has led some in radio broadcasting to lobby to require phone manufacturers to include radio broadcast access in their products (Shapiro, 2010). Accordingly, marketers will have to stay abreast of technological changes more than ever.

\section{LIMITATIONS}

The main limitation of this study was that the sample was a convenience sample rather than a scientifically chosen random sample, also the study was conducted at only one university to a majority of business students. The format of the survey may have skewed results by the failure to give participants the option to indicate they solely watch television online or through DVRs.

\section{CONCLUSION}

Technology is changing the manner in which students may view television programming. College students have unprecedented control over their reception or avoidance of advertising messages. This level of control allows them to view or not view television programming as they deem fit, where they deem fit, when they deem fit and how they deem fit. In the past, students could simply walk away or channel "surf" to avoid advertising messages. As technology progresses new avenues are opening to allow more access to students by programming managers. However, this same technology presents a conundrum to marketers as technology also offers additional means of advertising message avoidance.

\section{AUTHOR INFORMATION}

Katie J. Damratoski received a Master of Business Administration degree in July 2010 from Southeastern Louisiana University. Her concentrated areas of research include retail marketing and buyer awareness campaigns.

April R. Field received a Master in Business Administration degree in July 2010 from Southeastern. Her paper "Understanding and Confronting Alcohol-induced Risky Behavior Among College Students" was recently published in the Contemporary Issues in Education Research Journal. She enjoys researching areas relating to college student behavior.

Katie N. Mizell received her Master of Business Administration degree from Southeastern in Spring 2010. She enjoys researching how various types of technology are changing marketing practices.

Michael C. Budden is the Mayfield Professor of Marketing at Southeastern Louisiana University. His research interests include ethics, commercial law, business education and retail management.

\section{REFERENCES}

1. Atkinson, C. (2009, November 2). The Cable Industry Book-of-Record Homepage | Multichannel News. The Cable Industry Book-of-Record Homepage | Multichannel News. Retrieved March 23, 2010, from http://www.multichannel.com

2. Barkhuus, L. (Director) (2009, April 4). Television on the Internet: New practices, new viewers. CHI 2009. Lecture conducted from Association for Computing Machinery, Boston, MA. 
3. Budden, C., Anthony, J., Budden, M., \& Jones, M. (2007). Managing the evolution of a revolution: Marketing implications of internet media usage among college students. College Teaching Methods \& Styles Journal, 3(3), 7.

4. Dunne, P. M. and Lusch, R. F. (2008). Retailing, $6^{\text {th }}$. Thomson / Southwestern; Mason, Ohio.

5. $\quad$ Fitzgerald, Kate (2007, April 9). "Campus viewing stirs a rumpus." Advertising Age, S-8-S-8.

6. Grant, I., Kaminer, A. \& Lee, C. (n.d.). Institute for Research on Public Policy/Institut de recherche en politiques publiques (IRPP). Institute for Research on Public Policy/Institut de recherche en politiques publiques (IRPP). Retrieved March 24, 2010, from http://www.irpp.org/

7. Johnson, C. (2010, February 5). B\&T : Australia's highest-circulating advertising, marketing and media magazine. B\&T : Australia's highest-circulating advertising, marketing and media magazine. Retrieved March 31, 2010, from http://www.bandt.com.au

8. Jones, E. (Director) (2009, April 26). Network television streaming technologies and the shifting television social sphere. Media in Transition 6: Stone and Papyrus, Storage and Transmission. Lecture conducted from Massachusetts Institute of Technology, Cambridge, MA.

9. Jones, M., Budden, M.C., Budden, C.B. and Foster, J. F. A. (2007, September). Understanding the social network generation: A study of MySpace/Facebook usage among college students. In Proceedings of the Atlantic Marketing Association Conference, New Orleans, LA; 26-30.

10. Lamb, C. W. Jr., Hair, Jr., J. F. and McDaniel, C. (2006). Marketing, $8^{\text {th }}$. Thomson / Southwestern; Mason, Ohio.

11. Madden, M. (n.d.). Pew Research Center's Internet \& American Life Project. Pew Research Center's Internet \& American Life Project. Retrieved March 24, 2010, from http://www.pewinternet.org

12. Nelson, J. (2009, December 8). "Signs of the Times." Canadian Business: 38-39.

13. Nielsen | Profile. (n.d.). Nielsen | Home. Retrieved March 31, 2010, from http://enus.nielsen.com/main/about/Profile.

14. Noble, S. M., Haytko, D. L., and Phillips, J. (2009). What drives college-age Generation Y Consumers? Journal of Business Research, 62(6), 617-628.

15. Odell, P., Korgan, K., Schumacher, P., Delucchi, M. (2000). Internet use among female and male college students. Cyber Psychology \& Behavior, 3(5), 855-862.

16. Robbins, S. (2009, November 30). We need an online model, and fast. Broadcasting \& Cable, 6-7.

17. Schechner, S. \& Vranica, S. (2009, August 15). Corporate News: Media firms, advertisers study Nielsen alternative. The Wall Street Journal, Eastern Edition, B.5.

18. Selbert, D. R. (2009, December 1). The future of TV. Growth Strategies Newsletter, pp. 3-4. Retrieved March 24, 2010, from http://vlex.com/source/growth-strategies-3622/issue_nbr/\%231032

19. Shapiro, G. (2010, August 26). Don't Screw Up Our Cell Phones to Save Radio. Foxnews.com, retrieved October 4, 2010.

20. Steinberg, B. (2010, March 26). "CW plans TV-sized commercial breaks for online viewing." Advertising Age - Ad \& Marketing Industry News. Retrieved March 20, 2010 from http://adage.com/mediaworks/article?article_id=142998.

21. Steel, E. (2007, March 5). TV Networks launch big campus push; new Nielsen system makes college students coveted-ratings draw. The Wall Street Journal, p. B.3.

22. Vranica, S. (2007, November 8). TiVo serves up portrait of the ad-zappers; marketers are offered a look at subscribers, how they use DVRs. The Wall Street Journal, Eastern Edition, B.5.

23. Wilbur, K. (2008, Spring). How the Digital Recorder (DVR) Changes Traditional Television Advertising. Journal of Advertising, 71(1), 143-149. 